\begin{tabular}{|c|c|c|}
\hline 7 & Our Nature & $\begin{array}{l}\text { ISSN: 1991-2951 (Print) } \\
\text { ISSN: 2091-2781 (Online) }\end{array}$ \\
\hline 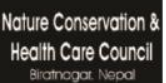 & Journal homepage: http://nepjol.info/index.php/ON & (c) ${ }_{\mathrm{BY}}$ (1) \\
\hline
\end{tabular}

\title{
Voice mimicry exhibited by Grey-sided Laughingthrush Garrulax caerulatus (Hodgson, 1836) in Phulchoki Mountain, an important bird area, central Nepal
}

\author{
Hem Sagar Baral \\ ZSL Nepal Office, PO Box 5867, Kathmandu, Nepal \\ School of Environmental Sciences, Charles Sturt University, NSW, Australia \\ Email:hem.baral@zsl.org
}

\begin{abstract}
DOI: http://doi.org/10.3126/on.v17i1.34004
Manuscript details: Received: 03.10.2019 / Accepted: 15.11 .2019

Citation: Limbu, D.K., M. Koirala and Z. Shang 2019. Effect of legume and grazing intensity on soil organic carbon and total nitrogen

stock in Himalayan rangeland. Our Nature 17 (1): 36-39. DOI: http://doi.org/10.3126/on.v17i1.34004

Copyright: Limbu, Koirala and Shang 2019. Creative Commons Attribution - Non Commercial 4.0 International License.
\end{abstract}

\section{Introduction}

There are 15 species of birds in Nepal known as laughingthrush (Grimmett et al., 2016; BCN and DNPWC, 2018). Most laughingthrushes are concentrated in the midhills habitat, but few species such as Variegated Laughingthrush Trochalopteron variegata is known to reach high altitude and has been recorded upto $4600 \mathrm{~m}$ (Inskipp et al., 2016). Two species of necklaced laughingthrushes Garrulax monileger and $G$. pectoralis and Rufous-necked Laughingthrush $G$. ruficollis are the only laughingthrushes that are confined to the lower foothills (Grimmett et al., 2016). In Nepal, therefore, midhills can be considered as the area with the highest diversity of laughingthrushes. As many as 12 species are found centred around the midhills with various level of abundance depending on east-west distribution limitations and altitude.

Ecology of many Himalayan birds is very little studied (Inskipp and Inskipp, 1991). In this regard, mid-hills dwelling Grey-sided Laughingthrush is not an exception. Since it was first described to science by Brian Hodgson (Hodgson, 1836) and its description on Fauna of British India (Baker, 1922), there are only a handful of papers published about its behavior and ecology. According to BirdLife International (2020), although the species' population is showing downtrend, the decline is not considered to keep this species under any threat category. Therefore, it is currently listed under Least
Concern category. Some observations of its behavior that are hitherto unknown to ecologists are noted in Phulchoki mountain, an important bird and biodiversity area (IBA) and are described in the following paragraphs.

\section{Observation}

During my regular birdwatching trips to Phulchoki, I observed Grey-sided Laughingthrush Garrulax caerulatus mimicking voices of Crested Serpent Eagle Spilornis cheela, Spotted Owlet Athene brama and Indian Cuckoo Cuculus micropterus on different occasions. I describe the voice mimicry behavior for three separate dates during my visit to Phulchoki.

On 21 October 2009, at the base of Phulchoki mountain, by the Godavari ravines, I located two Grey-sided Laughingthrushes at $1800 \mathrm{~m}$ asl about 1500 hrs. I was mimicking Collared Owlet Glaucidium brodei call when I saw and heard a pair of Grey-sided Laughingthrush produce thrush (Turdus spp., Monticola spp.) like melodious voice. It continued to produce several other bird species sounds that would be normally found at this altitude, unfortunately during my excitement I did not take note of what all of them really represented. However, I noted that one of the voices produced was well known and distinct calls of Indian Cuckoo Cuculus micropterus ! 'One more bottle!!' 


\section{Our Nature | December 2019 | 17 (1): 41-44}

On another occasion 4 November 2009, I noted six Grey-sided Laughingthrushes in a flock. These were located in dense thickets above Godavari ravines approximately $1850 \mathrm{~m}$ asl in the afternoon. Here too, I had been imitating Collared Owlet Glaucidium radiatum call trying to find new bird for the day in Phulchoki. Suddenly from dense thickets I heard a call that resembled Crested Serpent Eagle Spilornis cheela. On close inspection, to my amusement I found that the call was coming from one of the two Grey-sided Laughingthrushes perched on a horizontal branch.

On another occasion in Phulchoki in 2010, Spotted Owlet sound came from dense thickets but birds were not visible. I assumed that Greysided Laughingthrushes were making this sound considering the dense thickets more suitable habitat for Grey-sided Laughingthrush compared to the owlets. After having heard these unusual calls from Grey-sided Laughingthrush I later checked some documented knowledge about the species and its voice.

\section{Discussion}

Grey-sided Laughingthrush Garrulax caerulatus is a member of the family Leiotrichidae, and its world distribution is east from Taiwan, China, Myanmar, India, Bhutan and west to Nepal (del Hoyo et al., 2007). Nepal marks the western limit for the species' distribution (Ali and Ripley, 1987) and Annapurna Conservation Area is the most westerly locality within Nepal (Inskipp et al., 2016). In Nepal, the species is found in the midhills between 1370 to $2745 \mathrm{~m}$ (Grimmett et al., 2016) and inhabits dense, humid, subtropical broadleaf forests (Inskipp et al. 2016, Grimmett et al., 2016), particularly oak-rhododendron forests (Fleming et al., 1984). It has been described as a locally distributed resident and breeding has been proved in two places within Kathmandu Valley, Shivapuri and Phulchoki (Baral and Parr 2004, Inskipp et al. 2016). In Kathmandu valley, the species is an uncommon resident (Mallalieu, 2008), and at national level it is considered threatened for Nepal (Category: Vulnerable) because of loss and degradation of dense humid forest and bamboo (Inskipp et al. 2016). Although the population is suspected to be in decline globally owing to ongoing habitat destruction and fragmentation, the decline is not yet considered enough to warrant the species a threatened category on a global scale (BirdLife International, 2020).

In Phulchoki $\left(27^{\circ} 37^{\prime} \mathrm{N} / 85^{\circ} 16^{\prime} \mathrm{E}\right)$ and Shivapuri $\left(27^{\circ} 48^{\prime} \mathrm{N} / 85^{\circ} 23^{\prime} \mathrm{E}\right)$ mountains this species is known to associate with larger flocks of Whitethroated Laughingthrush G. albogularis, and occasionally with Chestnut-crowned Laughingthrush G. erythrocephalus and Rusty-cheeked Scimitar Babbler Pomatorhinus erythrogenys (Mallalieu, 2008). Compared to White-throated Laughingthrush, Grey-sided Laughingthrush is found in smaller flocks, normally upto six birds in a flock (Mallalieu, 2008). Both Phulchoki and Shivapuri form part of the network of 37 Important Bird and Biodiversity Areas (IBAs) spread throughout Nepal identified by BirdLife International (BCN and DNPWC in press). While Shivapuri mountain is part of the larger Shivapuri Nagarjun National Park and enjoys formal protection, Phulchoki lies outside the protected area network. The latter, however, is of exceptional value because of the conservation of top quality old growth forests. Phulchoki mountain is the number one midhill forest birding destination of the entire country.

The description of voice and calls by Baker (1922), Ali and Ripley (1987) already indicate possible mimicry by Grey-sided Laughingthrush. For two subspecies of the laughingthrush Baker (1922) states; 'said to have a very fine, almost human whistle which easily be imitated and by which it can be called up' (subspecies kaurensis) and 'Many of its notes are very full, soft and pleasant, but others are equally harsh and discordant (subspecies subcaerulatus)'. On both description, there is broadness in the characters leading to possible mimicry and less consistent voices. Please note Ali and Ripley (1987) state "Loud musical calls and liquid whistles, some of them rendered by Fleming as ovik-chorr, brain fever and new jericho (do si fa la)". The call 'brain fever' mentioned here is already an indication of voice mimicry of the Large Hawk Cuckoo Hierrococcyx sparveroides or Common Hawk Cuckoo H. cuculus, species recorded in the same habitat/altitude as that of Grey-sided Laughingthrush. Furthermore, Ali and Ripley (1987) write "One of its call-notes is a loud oh my dear". This again could be an indication of instant mimicry/copy of some people talking nearby?!

Scott Connop made a collection of two audio cassettes with bird songs of the Himalayas including Nepal (Connop, 1994;1995). He taped recording of Grey-sided Laughingthrush voices. The call sounds like mixed calls and song of various birds including a short strophe of Asian Koel Eudynamys scolopacea, the latter half of the song reminds the main portion of Large Hawk Cuckoo Hierococcyx sparveroides call. Both the 


\section{Our Nature | December 2019 | 17 (1): 41-44}

species can be frequently heard in the Grey-sided Laughingthrush habitat. Further, the species has been noted to be very vocal producing variety of different sounds (Suchit Basnet verbally 2020).

As many as 24 songs/calls have been described in Xeno-Canto (2019, https://www. xeno-canto.org/species/Garrulax-caerulatus) contributed by various recorders. None of these calls and songs match exactly to one another as one would expect for a normal bird. Recording made by George Wagner in Yunnan, China (XC23930) the last part is reminiscent of a Hawk Cuckoo call (Hierococcyx spp).

Del Hoyo et al. (2007) have given a large space in their definitive handbook to describe its voice compared to many other laughingthrushes. Although a large variety of voice forms has been described, voice mimicry has not been mentioned even once. Similarly, its voice has been described to have various forms in southeast Asia (Robson, 2008). Some forms having airy and whistles as well as raptor like squealing and rasp, mewing, rising then falling nyaoowl etc. Further it is said to have harsh grating when agitated. Rasmussen and Anderton (2012) spend considerable time in describing the voice of this laughingthrush and voice description appears to be one of the longest for laughingthrush species in their book. They state, 'songs are musical, arresting and strident, usually disjointed, explosive, impatient or jeering, they are given in many often surprising forms'. The authors then continue to describe the various voice forms of this species and of particular interest are: 'a series of raptor-like squeals'; 'first note quickly slurred up and down, middle notes flat and low, last prolonged, strongly upslurred and with a bell-like ending'; 'recalling a call of Rufous-chinned Laughingthrush Garrulax rufogularis'; 'mewing'; 'hiccupping'; 'guttural'; 'crowing' and 'strange, thin prolonged squeakyhinge notes'. There are too many forms described here and basically the summary is -it can be of any forms! Which then leads to possible voice mimicry.

Laughingthrushes are known to be quite vocal also having a wide vocabulary (Del Hoyo et al., 2007). For example, Striated Laughingthrush Garrulax striatus and Chestnut-crowned Laughingthrush G. erythrocephalus each of them produce at least half a dozen different songs and calls. Most of these calls tend to be in a regular pattern consistent and predictable.

There are indications that other laughingthrushes may also exhibit voice mimicry. In another independent observation, it has been found that Lesser Necklaced Laughingthrush Garrulax monileger once mimicking Red-wattled Lapwing Vanellus indicus in April 2000 at Chitwan National Park (Harka Man Gurung and Kapil Prasad Pokharel verbally 2013). Further information is lacking on this laughingthrush behavior particular to voice mimicry.

Prior to these observations, mimicry behaviour was not described for any species of laughingthrush. Indication of large variety of voice forms that is not regular, consistent is also an indication of voice mimicry. Based on above observations I conclude that the calls and songs described for far, in most cases, have included some form of voice mimicry of Grey-sided Laughingthrush. Further studies on the behavior and ecology of laughingthrushes including Greysided to clarify these facts and their usefulness would be a worthwhile project.

\section{Acknowledgements}

I would like to thank Nature Safari Tours Private Limited, Nepal and Naturetrek Limited, UK for facilitating my visit to the Phulchoki mountain forest. Thanks to Suchit Basnet for providing reference of Scott Connop's recordings and Carol Inskipp for kindly providing her comments on the draft of this paper.

\section{References}

Ali, S. and S.D. Ripley (1987) Compact handbook of the Birds of India and Pakistan. New Delhi: Oxford University Press.

Baker, E.C.S. (1922) The fauna of British India including Ceylon and Burma. Birds Vol 1. Second edition. Taylor and Francis, London.

Baral, H.S. and S.J. Parr (2004) On the breeding of Grey-sided Laughingthrush Garrulux caerulatus at Phulchoki. Danphe 13(3/4): 6.

BCN and DNPWC (2018) Birds of Nepal: an official checklist. Bird Conservation Nepal and Department of National Parks and Wildlife Conservation: Kathmandu.

$\mathrm{BCN}$ and DNPWC (in prep.) Important Bird and Biodiversity Areas of Nepal: key sites for conservation. Bird Conservation Nepal and Department of National Parks and Wildlife Conservation: Kathmandu.

BirdLife International (2020) Species factsheet: Garrulax caerulatus. Downloaded from http://www.birdlife.org on 15/01/2020.

Connop, S. (1994) Bird songs of Nepal. Cornell Laboratory of Ornithology, Library of Natural Sounds. Ithaca, New York.

Connop, S. (1995) Bird songs of the Himalayas. 


\section{Our Nature | December 2019 | 17 (1): 41-44}

Cornell Laboratory of Ornithology, Library of Natural Sounds. Ithaca, New York.

Del Hoyo, J., A. Elliott and D. Christie (2007) Handbook of the birds of the world: Picathartes to Tits and Chickadees. Barceola, Spain: Lyx Edicions.

Fleming, R.L. Sr, R.L. Fleming Jr, and L.S. Bangdel (1984) Birds of Nepal. Third edition. Kathmandu: Avalok.

Grimmett, R., C. Inskipp, T. Inskipp and H.S. Baral (2016) Birds of Nepal. London, UK: Christopher Helm.

Hodgson, B. H. (1836) Notices of the ornithology of Nepal. 1. Eight new species of Cinclosoma. Asiat. Res. 19: 143-150.

Inskipp, C., H.S. Baral, S. Phuyal, T.R. Bhatt, M. Khatiwada, T. Inskipp, A. Khatiwada, S. Gurung, P.B. Singh, L. Murray, L. Poudyal and R. Amin (2016) The status of Nepal's Birds: The national red list series. Zoological Society of London, UK.
Inskipp, C. and Inskipp, T. (1991) A guide to the birds of Nepal. Second edition. London, UK: Christopher Helm.

Mallalieu, M. (2008) Kathmandu Bird Report 2004-2006. Kathmandu: Bird Conservation Nepal.

Rasmussen, P.C. and J.C. Anderton (2012) Birds of South Asia. The Ripley Guide. Vols 1 and 2. Second edition. National Museum of Natural History - Smithsonian Institution, Michigan State University and Lynx Edicions, Washington DC, Michigan and Barcelona.

Robson, C. (2008) A field guide to the birds of south-east Asia. London, UK: New Holland Publishers.

Xeno-Canto (2019) (https://www.xeno-canto.org/ species/Garrulax-caerulatus). Checked on 19 January 2019. 